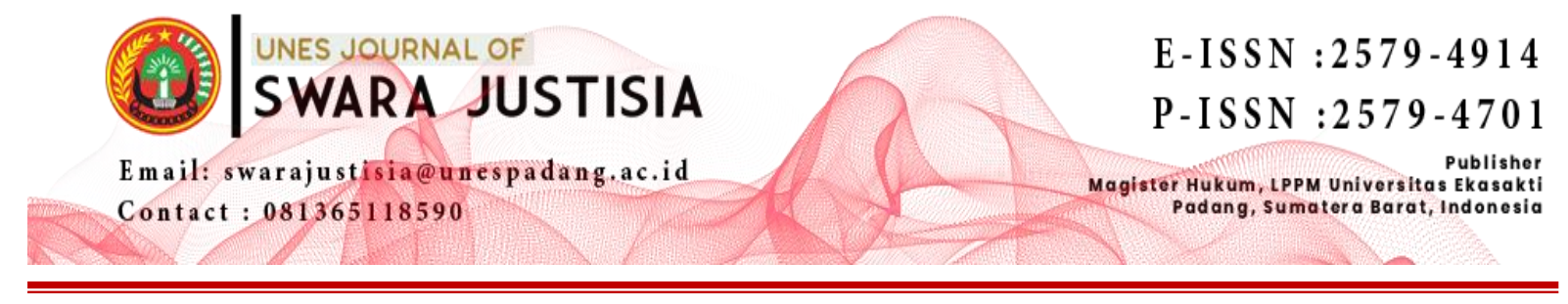

\title{
PENERAPAN UNSUR TINDAK PIDANA PERDAGANGAN ORANG OLEH PENYIDIK PADA DIREKTORAT RESERSE KRIMINAL UMUM POLDA SUMATERA BARAT
}

\author{
Nedra Wati \\ Program Magister Ilmu Hukum,Universitas Ekasakti, Padang \\ Email: nedra68914@gmail.com
}

\begin{abstract}
The application of elements of the crime of trafficking in persons by investigators is the first element of "everyone", each person referred to is a person who has committed a criminal act and can be held accountable to him. Third, the fulfillment of the element that recruits, transports, harbors, sends, transfers or receives a person, what is meant by "The person who recruits, transports, harbors, sends, transfers or accepts a person is that the suspect has done the things mentioned above against the victims. The obstacle faced by investigators at the Ditreskrimum Polda West Sumatra in applying the elements of the criminal act of trafficking in persons and how to overcome it is the lack of courage from the victim and witness to report the incident of the crime of trafficking in persons (human trafficking) to the investigators. Another obstacle to the investigation is the non-fulfillment of the elements in the criminal act of trafficking in persons (human trafficking). Crimes related to the crime of trafficking in persons (human trafficking) in the city of Padang, so far only apply the article in the Criminal Code, namely Article 296. In this case the article does not mention in detail the elements of the criminal act of trafficking in persons (human trafficking). , therefore the regulation is not as strict as that regulated in Law Number 21 of 2007 concerning the Eradication of the Crime of Trafficking in Persons.
\end{abstract}

Keywords: Investigation, Application of elements, Trafficking in persons, Crime

\begin{abstract}
ABSTRAK
Penerapan Unsur Tindak Pidana Perdagangan Orang Oleh Penyidik adalah yang pertama unsur "setiap orang", Setiap orang yang dimaksud adalah orang yang telah melakukan perbuatan pidana dan dapat dipertanggung jawabkan kepadanya. Ketiga, terpenuhinya unsur yang melakukan perekrutan, pengangkutan, penampungan, pengiriman, pemindahan atau penerimaan seseorang, yang dimaksud dengan "Yang melakukan perekrutan, pengangkutan, penampungan, pengiriman, pemindahan atau penerimaan seseorang adalah bahwa tersangka telah melakukan hal-hal sebagaimana tersebut di atas terhadap para korban. Kendala yang di hadapi oleh penyidik pada Ditreskrimum Polda Sumbar dalam penerapan unsur tindak pidana perdagangan orang dan cara mengatasinya adalah tidak adanya keberanian dari korban maupun saksi untuk melaporkan kejadian tindak pidana perdagangan orang (human trafficking) tersebut kepada pihak penyidik. Hambatan penyidikan lainnya adalah tidak terpenuhinya unsur-unsur yang ada dalam tindak pidana perdagangan orang (human trafficking). Tindak pidana yang ada kaitannya dengan tindak pidana perdagangan orang
\end{abstract}


(human trafficking) di Kota Padang, sejauh ini hanya menerapkan pasal dalam KUHP yaitu Pasal 296. Dalam hal ini pasal tersebut tidak menyebutkan secara terperinci mengenai unsurunsur tindak pidana perdagangan orang (human trafficking), oleh karena itu pengaturannya tidak begitu tegas seperti yang diatur dalam Undang-Undang Nomor 21 Tahun 2007 tentang Pemberantasan Tindak Pidana Perdagangan Orang.

Kata Kunci: Penyidikan, Penerapan unsur, Perdagangan orang, Tindak Pidana

\section{PENDAHULUAN}

Masalah perdagangan orang dan atau dikenal dengan istilah human trafficing akhirakhir ini muncul menjadi suatu masalah yang banyak diperdebatkan baik dari tingkat regional maupun global dan diakibatkan sebagai bentuk perbudakan masa kini, sebenarnya perdagangan manusia bukanlah hal yang baru, namun beberapa tahun belakangan ini, masalah ini muncul di permukaan dan menjadi perhatian tidak saja pemerintah Indonesia, namun juga telah menjadi masalah transnasional. ${ }^{1}$

Substansinya sama, yaitu perbudakan, tetapi modusnya yang lebih rapi dan terencana. Jika pada zaman perbudakan, manusia secara terang-terangan diperjualbelikan oleh raja atau yang lainnya untuk dijadikan gundik (pembantu) serta menjadi selir atau istri simpanan, saat ini manusia diperjualbelikan untuk kepentingan tertentu, seperti pembantu rumah tangga hingga menjadi wanita pekerja seks komersial. ${ }^{2}$

Dalam sejarah bangsa Indonesia perdagangan Manusia pernah ada melalui perbudakan atau penghambaan. Masa kerajaan-kerajaan dijawa, perdagangan manusia, yaitu perempuan pada saat itu merupakan bagian pelengkap dari system pemerintahan feodal. Pada masa itu konsep kekuasaan raja digambarkan sebagai kekuasaan yang sifatnya agung dan mulia. $^{3}$

Perdagangan manusia yang mayoritas perempuan dan anak, merupakan jenis perbudakan pada era modern ini merupakan dampak krisis multidimensional yang dialami Indonesia. Dalam pemberitaan saat ini sudah dinyatakan sebagai masalah global yang serius dan bahkan telah menjadi bisnis global yang telah memberikan keuntungan besar terhadap pelaku. Dari waktu ke waktu praktik perdagangan orang semakin menunjukkan kualitas dan kuantitasnya. setiap tahun diperkirakan 2 (dua) juta manusia diperdagangkan dan sebagian besarnya adalah perempuan dan anak ${ }^{4}$ tahun 2005, ILO Global Report on Forced Labour memperkirakan hampir 2,5 juta orang diekploitasi melalui perdagangan orang menjadi buruh diseluruh dunia, dan lebih dari setengahnya berada diwilayah asia dan pasifik dan $40 \%$ anakanak. $^{5}$

Kitab Undang-undang Hukum Pidana (KUHP) hanya memiliki satu pasal saja, yaitu pasal 297 yang mengatur secara eksplisit tentang perdagangan perempuan dan anak laki-laki, tetapi ancaman hukumannya masih ringan. Perdagangan anak juga belum diantisipasi oleh Undang-Undang Nomor 4 Tahun 1979 Tentang Kesejahteraan Anak, yang dimaksudkan

\footnotetext{
${ }^{1}$ Harlan Miranda dan Sutik A.S, Burung-Burung Migran, Qanita, Jakarta, 2011, hlm 3

${ }^{2}$ Adon Nasrullah Jamaludin, Dasar-Dasar Patologi Sosial, Pustaka Setia,Bandung, 2016, hlm. 227

${ }^{3}$ Farhana, Aspek Hukum Perdagangan Orang Di Indonesia, Sinar Grafika, Jakarta, 2010, hlm. 1

${ }^{4}$ Rachmad Syafaat, Dagang manusia, Lappera Pustaka Utama, Jakarta, 2003, hlm. 1.

5 Kantor Kejaksaan RI (Pusdiklat), Perdagangan manusia dan UndangUndang Ketenagakerjaan, Strategi Penuntutan yang Efektif, Kejaksaan Agung Republik Indonesia, Jakarta 2008, hlm 33
} 
untuk memberikan perlindungan hukum kepada anak dan dinyatakan oleh US Departemen of State Publication 2005 bahwa Indonesia sebagai Negara sumber dan transit perdagangan orang internasional, khususnya untuk tujuan seks komersial dan buruh anak didunia. Dampak dari perdagangan orang ini Indonesia terancam dihentikan seluruh bantuan kemanusiaan dari dunia internasional. ${ }^{6}$

Menurut Global Alliance Agains Traffic in Women (GAATW) tentang Perdagangan Perempuan Adalah "Semua usaha atau tindakan yang berkaitan dengan perekrutan, transportasi didalam atau melintas perbatasan, pembelian, penjualan, transfer, pengiriman atau penerimaan seseorang dengan menggunakan penipuan atau tekanan termasuk penggunaan atau ancaman Penggunaan kekerasan atau penyalahgunaan kekerasan atau lilitan utang dengan tujuan untuk menempatkan atau menahan orang tersebut, baik dibayar atau tidak untuk kerja yang tidak diinginkan (domestik, seksual, atau reproduktif) dalam kerja paksa atau ikatan kerja atau dalam kondisi seperti perbudakan didalam suatu lingkungan lain dari tempat dimana orang itu tinggal pada waktu penipuan, tekanan atau lilitan utang pertama kali". 7

Undang-undang Nomor 21 tahun 2007 tentang "Pemberantasan Tindak Pidana Perdagangan Orang (PTPPO)" melarang semua jenis tindakan, cara, atau semua bentuk eksploitasi yang mungkin terjadi dalam praktek perdagangan orang. Baik yang dilakukan antar wilayah dalam negeri mauun antar negara baik pelaku perorangan maupun korporasi. Berdasarkan bukti empiris, perempuan dan anak-anak adalah kelompok yang paling banyak dimintai korban Tindak Pidana Perdagangan Orang, korban perdagangan orang tidak hanya untuk tujuan pelacuran atau bentuk eksploitasi lain misalnya kerja paksa atau pelayanan paksa, perbudaknya atau praktisi sejenis itu. ${ }^{8}$

Kepolisian Daerah Sumatera Barat, melakukan penyidikan terhadap praktek prostitusi yang berkedok rumah kosan di jalan Adi Negoro, Kelurahan Lubuk Buaya, Kecamatan Koto Tangah, Kota Padang. Tersangka diketahui dua orang yang merupakan ibu dan anak, dengan perannya sebagai mucikari. Selain kedua pelaku, polisi juga mengamankan tiga orang wanita yang mana satu di antaranya masih di bawah umur. Ketiganya ditetapkan sebagai korban atas kasus Tindak Pidana Perdagangan Orang (TPPO). Pada penyidikan tindak pidana ini penyidik mengalami berbagai kesulitan dalam penerapan unsur tindak pidana perdagangan orang berdasarkan alat bukti yang terkumpul dikarenakan berkedok rumah kost-kostan.

Permasalahan yang dibahas adalah penerapan unsur tindak pidana perdagangan orang oleh penyidik pada Direktorat Reserse Kriminal Umum Polda Sumatera Barat

\section{METODE PENELITIAN}

Spesifikasi penelitian adalah deskriptif analitis, dengan metode pendekatan yuridis normative didukung yuridis empiris. Jenis data yang digunakan adalah data sekunder dan data primer. Data sekunder diperoleh dari studi dokumen sedangkan data primer dari studi lapangan. Data yang diperoleh kemudian dianalisa secara kualitatif.

${ }^{6}$ Tubagus Rachmat Sentika, Fenomena Perdagangan Perempuan dan Anak di Indonesia, Mitra Gender,Jakarta, 2006, hlm.1.

${ }^{7}$ Yentriyani Andy, Politik Perdagangan Perempuan, Galang Press, Yogyakarta, hlm.12. 2012, hlm 5

${ }^{8}$ Moh. Hatta, Tindak Pidana Perdagangan Orang Dalam Teori Dan Praktek, Liberty Yogyakarta, 


\section{PEMBAHASAN}

\section{A. Penerapan Unsur Tindak Pidana Perdagangan Orang Oleh Penyidik}

Berdasarkan Undang-undang Nomor 21 Tahun 2007, ruang lingkup tindak pidana perdagangan orang mengandung unsur objektif dan unsur subjektif, Dalam kasus yang penulis angkat dalam penelitian ini telah memenuhi beberapa unsur tindak pidana perdagangan orang. Diantaranya,pertama terpenuhinya unsur "setiap orang", Setiap orang yang dimaksud adalah orang yang telah melakukan perbuatan pidana dan dapat dipertanggung jawabkan kepadanya dalam perkara ini adalah tersangka Helen Nurdin Pgl ELEN telah terpenuhi dengan alat bukti berupa keterangan saksi, keterangan tersangka, serta nukti-bukti.

Kemudian kedua pada unsur "terhadap anak" juga terpenuhi, yang dimaksud dengan "Anak" dalam Pasal 1 ayat (1) Undang-Undang Nomor 23 Tahun 2002 Tentang Perlindungan Anak, adalah seseorang yang belum berumur 18 (delapan belas) tahun termasuk anak yang masih dalam kandungan. Unsur ini terpenuhi dengan alat bukti diantaranya, keterangan saksi-saksi, Surat, Adanya keterangan tersangka, dan petunjuk. Selanjutnya juga terpenuhinya unsur dilarang, menempatkan, membiarkan, melakukan, menyuruh melakukan, atau turut serta melakukan eksploitasi secara ekonomi dan atau seksual, yang dimaksud dengan "dengan ancaman kekerasan, penculikan, penyekapan, pemalsuan, penipuan, penyalah gunaan kekuasaan atau posisi rentan, penjeratan utang atau memberi bayaran, atau manfaat walaupun memperoleh persetujuan dari orang yang memegang kendali atas orang lain adalah dalam hal ini tersangka Helen Nurdin telah melakukan hal-hal sebagaimana tersebut diatas dan unsur ini terpenuhi dengan alat bukti berupa adanya keterangan saksi-saksi, Adanya barang bukti, Adanya keterangan tersangka, dan petunjuk.

Ketiga, terpenuhinya unsur yang melakukan perekrutan, pengangkutan, penampungan, pengiriman, pemindahan atau penerimaan seseorang, yang dimaksud dengan "Yang melakukan perekrutan, pengangkutan, penampungan, pengiriman, pemindahan atau penerimaan seseorang adalah bahwa tersangka telah melakukan hal-hal sebagaimana tersebut di atas terhadap para korban dalam hal ini Unsur tersebut terpenuhi dengan alat bukti berupa: Adanya keterangan saksi-saksi, Adanya keterangan tersangka, dan adanya petunjuk.

Kemudian keempat, terpenuhinya unsur dengan ancaman kekerasan, penculikan, penyekapan, pemalsuan, penipuan, penyalah gunaan kekuasaan atau posisi rentan, penjeratan utang atau memberi bayaran, atau manfaat walaupun memperoleh persetujuan dari orang yang memegang kendali atas orang lain. yang dimaksud dengan "dengan ancaman kekerasan, penculikan, penyekapan, pemalsuan, penipuan, penyalah gunaan kekuasaan atau posisi rentan, penjeratan utang atau memberi bayaran, atau manfaat walaupun memperoleh persetujuan dari orang yang memegang kendali atas orang lain adalah dalam hal ini tersangka Helen Nurdin telah melakukan hal-hal sebagaimana tersebut diatas dan unsur ini terpenuhi dengan alat bukti berupa adanya keterangan saksisaksi, Adanya keterangan tersangka, Adanya barang bukti, adanya petunjuk.

Kelima, Terpenuhinya unsur "untuk tujuan mengekploitasi orang tersebut di wilayah Negara Republik Indonesia", Yang dimaksud dengan Unsur "Untuk tujuan mengekploitasi orang tersebut diwilayah Negara republik Indonesia" dalam pasal ini 
adalah bahwa terjadinya ekploitasi terhadap orang tersebut terjadi diwilayah negara republik Indonesia dalam hal ini ekploitasi itu terjadi di rumah tersangka Jl. Adinegoro No.19/20 Lubuk Buaya Kota Padang Provinsi Sumatera Barat yang mana wilayah tersebut adalah wilayah Negara republik Indonesia telah terpenuhi dengan alat bukti diantaranya Adanya keterangan saksi, adnya keterangan tersangka, dan adanya petunjuk.

Keenam, terpenuhinya unsur "Jika Tindak Pidana sebagaimana dimaksud dalam Pasal 2, Pasal 3, dan Pasal 4 dilakukan terhadap anak maka ancaman Pidanannya ditambah 1/3 (sepertiga)" Yang dimaksud dengan unsur Jika Tindak Pidana sebagaimana dimaksud dalam Pasal 2, Pasal 3, dan Pasal 4 dilakukan terhadap anak maka ancaman Pidanannya ditambah $1 / 3$ (sepertiga) dalam hal ini adalah bahwa terhadap orang lain atau korban ekploitasi tersebut masih dalam usia anak yaitu seseorang yang belum berusia 18 (delapan belas tahun), adapun fakta-fakta yang dapat diungkap untuk memenuhi unsur pasal ini yakni, adanya keterangan saksi, adanya surat, dan adanya petunjuk.

Berdasarkan hasil penelitian yang telah penulis lakukan di Ditreskrimum Polda Sumbar bahwa dalam melakukan penyidikan suatu tindak pidana yang khususnya tindak pidana perdagangan orang (human trafficking) di Kota Padang telah diketemukan kendala, sehingga dalam pelaksanaan penyidikan tersebut menjadi terhambat. Hambatan tersebut bertumpu pada unsur-unsur yang ada dalam tindak pidana perdagangan orang (human trafficking) yang dijelaskan pada pembahasan sebelumnya mengenai unsur-unsur tindak pidana itu. Dalam hal ini jika suatu berkas dalam penyidikan tindak pidana tersebut belum lengkap (P19) ataupun belum mencakup semua unsur dari tindak pidana tersebut maka belum dapat diketegorikan ke dalam tindak pidana perdagangan orang (human trafficking). Jika tindak pidana tersebut sudah mencakup semua unsurnya, maka dapat dikatakan tindak pidana tersebut sebagai tindak pidana perdagangan orang (human trafficking) dan dapat diberlakukannya Undang-Undang Nomor 21 Tahun 2007 tentang Pemberantasan Tindak Pidana Perdagangan Orang. Oleh karena itu unsur-unsur yang ada dalam tindak pidana perdagangan orang (human trafficking) harus terpenuhi semuanya, sehingga Undang-Undang Nomor 21 Tahun 2007 tentang Pemberantasan Tindak Pidana Perdagangan Orang itu dapat diterapkan.

Penyidikan kasus human trafficking sebaiknya ditangani oleh gugus tugas atau unit yang multi disipliner, dengan mana dapat dijalin kerjasama yang baik dengan dinas atau departemen lainnya. Bagaimana komposisi keanggotaan unit tersebut akan bergantung pada kasus konkrit yang dihadapi dan keahlian khusus yang dibutuhkan.

\section{B. Kendala Yang Dihadapi Oleh Penyidik Pada Ditreskrimum Polda Sumbar Dalam Penerapan Unsur Tindak Pidana Perdagangan Orang Dan Cara Mengatasinya}

Berdasarkan hasil penelitian yang telah penulis lakukan di Ditreskrimum Polda Sumbar memperoleh hasil bahwa dalam melakukan penyidikan tindak pidana perdagangan orang (human trafficking) di Kota Padang telah diketemukan kendala, sehingga dalam pelaksanaan penuntutan tersebut menjadi terhambat. Hambatan tersebut juga bertumpu pada tidak terpenuhinya unsur-unsur yang ada dalam tindak pidana perdagangan orang (human trafficking) yang dijelaskan pada pembahasan sebelumnya mengenai unsur-unsur tindak pidana itu. Dalam hal ini jika hasil penyidikan tindak pidana tersebut belum lengkap (P19) ataupun belum mencakup semua unsur dari tindak 
pidana tersebut maka belum dapat diketegorikan ke dalam tindak pidana perdagangan orang (human trafficking). Jika suatu tindak pidana tersebut sudah memenuhi unsurnya, maka dapat dikatakan tindak pidana tersebut sebagai tindak pidana perdagangan orang (human trafficking) dan dapat diberlakukannya Undang-Undang Nomor 21 Tahun 2007 tentang Pemberantasan Tindak Pidana Perdagangan Perdagangan Orang.

Kebijakan operasional menjadi sangat penting untuk dikritisi karena implementasi dari upaya pemberantasan perdagangan orang akan dilakukan berdasarkan peraturan-peraturan ini. Sebagai contoh, sebagaimana dimandatkan Pasal 46 ayat 1 dan 2 UU PTPPO, pemerintah Indonesia menetapkan Peraturan Pemerintah Nomor 9 Tahun 2008 tentang Tata Cara dan Mekanisme Pelayanan Terpadu Bagi Saksi dan/atau Korban Tindak Pidana Perdagangan Orang, yang akan dikembangkan di setiap kabupaten/kota bagi saksi dan/atau korban perdagangan orang. Peraturan Pemerintah ini kemudian mengamanatkan dibuatnya Peraturan Menteri mengenai Standar Pelayanan Minimal dan Standar Prosedur Operasional mengenai pemulangan dan integrasi. Sehingga dengan demikian, sinergitas vertikal antar peraturan tersebut di atas menjadi sangat penting dalam upaya pemberantasan dan pencegahan perdagangan orang.

Dalam mengatasi problematika pelaksanaan kendala penyidikan dan penuntutan tindak pidana perdagangan orang (human trafficking) pada intinya sama yaitu diperlukan adanya undang-undang yang lain (juncto) yang dalam hal ini jika suatu perkara tersebut unsur-unsurnya tidak dapat masuk ataupun belum lengkapnya unsur tersebut ke dalam tindak pidana perdagangan orang (human trafficking), maka jalan satu-satunya diberlakukannya undang-undang yang lain yang sesuai dengan tindak pidana tersebut. Misalkan ada suatu kasus tentang penipuan terhadap seseorang, dalam hal ini unsur tindak pidana perdagangan orang tersebut hanya satu saja yaitu penipuan, maka hanya dikenakan pasal dalam KUHP tepatnya Pasal 378. Dalam penerapan ke dalam undangundang lain dapat juga dipergunakan dua undang-undang, yang dalam artian undangundang tersebut dapat saling melengkapi satu sama lain sehingga diharapkan kemungkinan terkecil tidak adanya kekeliruan dalam penjatuhan hukuman terhadap para pelakunya dan membuat para pelakunya menjadi jera.

Kendala yang dihadapi Polri dalam penanganan perdagangan perempuan di wilayah Sumatera Barat adalah: TPPO dilakukan dengan pola jaringan terputus, keterbatasan sumber daya kepolisian, disintegrasi data kepolisian terkait korban dan pelaku TPPO, disintegrasi data kependudukan dan keimigrasian, rentang kendali pengawasan pengendalian serta parsialitas penanganan antar aparat penegak hukum dengan masyarakat. Perdagangan Orang dilakukan dengan pola jaringan terputus. Hal ini yang menyulitkan dalam penanganan atau pencegahan terjadinya perdagangan manusia. Jaringan terputus mulai dari perekrutan, pengangkutan, penampungan. Hubungan antara sponsor dan agen di kota dan desa sampai korban terbatas pada hubungan transaksional. Polisi kesulitan ketika TKP (kekerasan dan penganiyaan) berada di luar negeri yang mengharuskan polisi harus bekerja sama dengan instansi lain di luar negeri. Salah seorang informan mengaku sudah membuat laporan ke Polda Sumatera Barat, namun belum mendapat respon, hal tersebut diungkapkan dalam pernyataannya: Sudah dua minggu laporan, tetapi tidak ada kunjung berita.

Personel penyidik yang memililiki spesialis TPPO dan berlatar belakang sarjana 
masih sangat terbatas. Anggaran untuk penyeidikan dan penyidikan terbatas, anggaran peningkatan kompetensi untuk penyidik juga terbatas. Kendala lain terkait database yang terintegrasi belum ada, baik antar satuan wilayah maupun antara Mabes dengan kewilayahan, padahal karakteristik dari kejahahatan TPPO ini lintas daerah bahkan lintas negara. Disintegrasi data kepolisian terkait korban dan pelaku dengan keterbatasan anggaran memperumit penanganan perdagangan perempuan. Data terkait perempuan yang dipulangkan ke Sumatera Barat dari wilayah di luar Sumatera Barat terkait tndak pidana perdagangan orang, tidak diketahui oleh Polres jajaran Polda Sumatera Barat. Kalaupun ada yang diketahui, maka pengetahuan itu diperoleh dari informasi tradisional antar Polres, umumnya terjadi pada kasus "atensi". Disintegrasi data kependudukan dan keimigrasian terjadi karena belum ada online system yang bisa mengakses data-data keimigrasian dan kependudukan. Permintaan data kepada kedua instansi tersebut dilakukan secara tradisional, jika Polri memerlukan, maka harus mengajukan ke instansi pusat. Prosedur ini memperlambat bahkan mempersulit dalam penanganan TPPO. Rentang kendali pengawasan pengendalian cenderung memberikan celah bagi terjadinya perdagangan perempuan. Penanganan terhadap tindak pidana perdagangan orang selayaknya didukung oleh database yang lengkap, terintegrasi, sehingga proses perencanaan strategi, pelaksanaan dan pendataan dilakukan secara komprehensif. Parsialitas penanganan hukum antar aparat penegak hukum disebabkan tidak adanya online system dalam mengkases data yang ada di setiap instansi yang terkait dengan perdagangan orang. Pemerintah daerah sebagai instansi koordinator yang bertanggung jawab dalam pencegahan dan pembinaan warga masyarakat terhadap perdagangan orang masih belum pro-aktif melakukan sinergitas antar instansi yang terkait dengan perdagangan orang. Misalnya, instansi pemerintahan di tingkat desa/ kelurahan belum memiliki sistem peringatan dini terkait dengan permintaan surat keterangan untuk melakukan kegiatan yang bisa berpotensi terjadinya perdagangan orang, misalnya ijin pernikahan dengan warga negara asing, bekerja di luar kota, dan lain-lain.

Strategi yang dapat dilakukan Polri guna mengoptimalkan penanganan perdagangan perempuan yaitu: sosialisasi kepada masyarakat, pemakaian bersama sumber daya kepolisian dengan teknologi informasi, sinergitas Polri dengan pihak eksternal, reskilling kompetensi penyidik melalui Pendidikan Pelatihan (Diklat), mengintegrasikan data korban dan pelaku TPPO menjadi database Mabes Polri yang terintegrasi dalam jangka pendek dan database nasional dalam jangka menengah, review penganggaran penanganan TPPO dan penerapan manajemen pengetahuan. Pemahaman Masyarakat Tentang TPPO Rendah. Perubahan sosial yang terjadi perkotaan berdampak pada kehidupan masyarakat pedesaan, terutama di daerah pinggiran kota. Kehidupan di kota merupakan impian dikalangan sebagian warga pedesaan, terutama remaja gadis untuk bisa mengikuti gaya hidup perkotaan. Faktor ini mendorong mereka ingin bekerja di kota, yang seringkali tidak sepengetahuan orangtua mereka jika kepergian bekerja di kota terjebak dalam perdagangan orang karena diiming-imingi gaji besar dan fasilitas lain yang dijanjikan. Sementara itu, disisi lain, orang tua tidak begitu paham benar tentang seluk beluk kehidupan di kota, sehingga seringkali orang tua memberikan ijin dan restu begitu saja. Peran tokoh masyarakat dan agama serta kepala desa/lurah relatif tidak berjalan karena kemungkinan juga tidak paham tentang perdagangan manusia, 
bekerja di bawah umur, dan lain-lain. Sosialisasi TPPO kepada masyarakat terutama di desa-desa pemasok TKW dan desa miskin sangat mendesak dilakukan dengan melibatkan pemerintah daerah. Terkait dengan hal tersebut, perlu dilakukan pemetaan potensi rawan TPPO di suatu wilayah hukum kepolisian. Langkah awal yang perlu dilakukan adalah membangun database dan pemetaan desa rawan perdagangan orang. Penggunaan IT ini perlu disinergikan secara on line dengan Pemda yang menangani perdagangan orang dan penggunaan tenaga kerja di bawah umur. Database merupakan sumber daya yang dapat digunakan secara bersama, sehingga mempermudah pengawasan dan penanganan terkait tindak pidana perdagangan orang. Sinergitas dengan instansi luar sangat dibutuhkan untuk menuntaskan bahwa perkara yang ditangani benarbenar terdapat unsur-unsur TPPO, dan tidak berhenti kasus penggunaan tenaga kerja di bawah umur. Kecenderungan perkara TPPO tidak lepas dari korban yang berada jauh dari TKP. Oleh karena itu, sinergitas dengan Pemda perlu dijalin agar persoalan perdagangan orang dari hulu ke hilir dapat ditangani dengan baik. Tantangan lain yang dihadapi penyidik TPPO adalah minimnya pengetahuan tentang perdagangan manusia. Idealnya perlu adanya Pendidikan Kejuruan (Dikjur) tentang masalah perdagangan orang, namun anggaran peningkatan kompetensi penyidik belum selaras dengan kebutuhan. Selain itu, jumlah dan pola penganggaran TPPO dapat direview agar dapat menutupi kebutuhan riil penganganan TPPO. Penerapan manajemen pengetahuan diperlukan untuk peningkatan pengetahuan tentang TPPO. Hal tersebut dapat dilakukan dengan diskusi bersama dengan LSM yang peduli perdagangan orang atau melakukan rapat kerja atau lokakarya dengan instansi teknis lainnya. Manajemen pengetahuan yang dilakukan dengan baik berimplikasi positif terhadap optimalisasi penanganan perdagangan orang, dalam hal ini khususnya perdagangan manusia. Hal tersebut disebabkan manajemen pengetahuan memberikan ekses peningkatan pengetahuan dengan menghemat biaya khusus Diklat atau Dikjur.

\section{PENUTUP}

Penyidikan kasus human trafficking sebaiknya ditangani oleh gugus tugas atau unit yang multi disipliner, dengan mana dapat dijalin kerjasama yang baik dengan dinas atau departemen lainnya. Bagaimana komposisi keanggotaan unit tersebut akan bergantung pada kasus konkrit yang dihadapi dan keahlian khusus yang dibutuhkan. Indikasi adanya tindak pidana human trafficking haruslah diikuti dengan penyelidikan/penyidikan, dan bila memungkinkan, dilanjutkan dengan penuntutan.

\section{DAFTAR PUSTAKA}

Adon Nasrullah Jamaludin, Dasar-Dasar Patologi Sosial, Pustaka Setia,Bandung, 2016

Farhana, Aspek Hukum Perdagangan Orang Di Indonesia, Sinar Grafika, Jakarta, 2010

Harlan Miranda dan Sutik A.S, Burung-Burung Migran, Qanita, Jakarta, 2011

Kantor Kejaksaan RI (Pusdiklat), Perdagangan manusia dan Undang-Undang Ketenagakerjaan, Strategi Penuntutan yang Efektif, Kejaksaan Agung Republik Indonesia, Jakarta 2008

Moh. Hatta, Tindak Pidana Perdagangan Orang Dalam Teori Dan Praktek, Liberty Yogyakarta, 2012 
Rachmat Sentika, Fenomena Perdagangan Perempuan dan Anak di Indonesia, Mitra Gender, Jakarta, 2006

Tubagus Rachmad Syafaat, Dagang manusia, Lappera Pustaka Utama, Jakarta, 2003

Yentriyani Andy, Politik Perdagangan Perempuan, Galang Press, Yogyakarta 